\title{
Study on the Mechanism of Antibiotic Resistance
}

\author{
LETITIA DOINA DUCEAC ${ }^{1}$, ELENA TARCA2, MADALINA IRINA CIUHODARU², MARINELA MONICA TANTU3*, \\ ROXANA ELENA BOGDAN GOROFTEI ${ }^{4}$, ELENA ARIELA BANU4, DANIELA DAMIR ${ }^{2}$, MIHAI GLOD²*, ALINA COSTINA LUCA ${ }^{2}$ \\ ${ }^{1}$ Apollonia University of lasi, Faculty of Medicine, Academician Ioan Haulica Institute of Researches, 2 Muzicii Str., 700399, Iasi, \\ Romania \\ ${ }^{2}$ Grigore T. Popa University of Medicine and Pharmacy, Faculty of Medicine, 16 University Str., 700115, Iasi, Romania \\ 3University of Pitesti, Faculty of Sciences, Department of Medical Care, Assistance and Kinesiotherapy, 1 Targu din Vale, Str., \\ 110040, Pitesti, Romania \\ ${ }^{4}$ University Dunarea de J0s, Faculty of Medicine and Pharmacy, 47 Domneasca Str., 800008, Galati, Romania
}

\begin{abstract}
A major public health threat that affects humans is recognized worldwide as an occurrence of antibiotic resistance regarding bacterial pathogen. Multidrug resistant microorganisms appeared in the hospitals and in the community settings respectively insinuating that the antibiotic-resistant bacteria are present even outside the hospital environment. First stage of bacterial adaptation and the top of evolution is represented by the bacterial response to the drug assault. Then, the survival of the fittest is a consequence of the biochemical and genetically alteration. Therefore, of extreme importance are the innovative methods and devices for therapeutic approaches against antibiotic-resistant microorganisms.
\end{abstract}

Keywords: antibiotic, multidrug-resistance, bacteria, IR spectroscopy, healthcare associated infections, child.

A worldwide healthcare problem in last few years is represented by bacterial infections because of their resistance to commonly used antibiotics. There are studies that indicate high rates of microbial resistance in developing countries. Routine administration of antimicrobial drugs have become of major importance for medical approaches. Thus, antibiotics efficacy was jeopardized by a growing number of pathogens which are antibiotic-resistant. Antibioresistance is considered a global public health threat being implicated in elevated mortality and morbidity rates as a consequence of hospitalization [1-3]. Studies revealed that between $3 \%$ and $5 \%$ of hospitalized patients leave the care unit acquiring healthcare-associated infections [4-13]. The most widely used antibiotics to treat some bacterial infections by inhibiting cell wall biosynthesis are â- lactam antibiotics. In the past decades, extensive researches have focused on discovering novel compounds that inhibit $\beta$ lactamase function in order to counteract $\beta$-lactam resistance bacteria [13-15]. Another class of important antibiotics used to treat various bacterial pathogens is aminoglycosides. The mechanism of aminoglycoside resistance is represented by the generation of aminoglycoside-modifying enzymes [16, 17]. A successful bacterial strategy to stand up to the presence of antibiotics is the production of enzymes that inactivate the drug by attaching specific chemical moieties to that compound or to destroy the drug itself making thus the antibiotic incapable to action on its target. Is a mechanism of acquired antibiotic resistance in both Gram $(+)$ and Gram(-) bacteria [18-25].

\section{Experimental part}

Materials and methods

The present study was conducted in a hospital unit for children for a three years period, concerning acquired healthcare associated infections. It is a descriptive and observational study which involved 461 patients of different ages hospitalized in a clinical unit. The subjects developed one or more healthcare associated infections. Data processing was performed according to various demographic, etiological and clinical-epidemiological parameters by using statistical and mathematical methods.

\section{Results and discussions}

Between 2014-2016 in the children's hospital considered in the study there were 461 of healthcare associated infections. In 2014 and 2015 was registered 0.44 percent and 0,38 percent of infections respectively. In the last year, 2016 the percent of healthcare associated infections was 0,76 having an important increase due to diarrheal disease with rotavirus which is specific to cold season and being contagious to the infant. On the other side, providing additional data and having a great contribution was the introduction of screening for multi-resistantantibiotic germ infection.

Regarding the antibiotic of age-related infections (fig. 1 ), the study revealed that the group of 1-4 years has an increased vulnerability of the immune system.

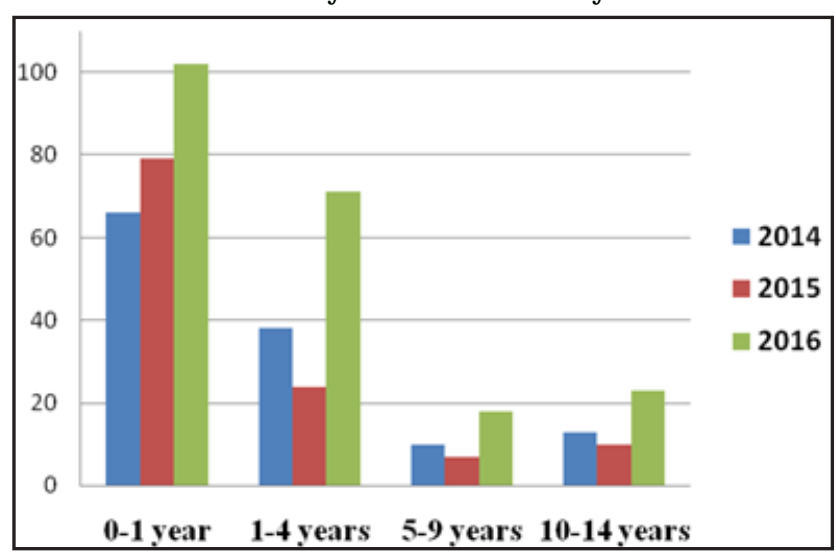

Fig.1. Distribution of HAl by age group, 2014-2016

From figure 2 it can be observed that the distribution of HAl related to clinical entities presents a high incidence of respiratory infections and surgical wound infections followed by catheter infections, skin infections (most of them caused by burns), septicemia, urinary infections, and

*email: tantumonica@yahoo.com,mihai_glod@yahoo.com All authors contributed equally to this work. 


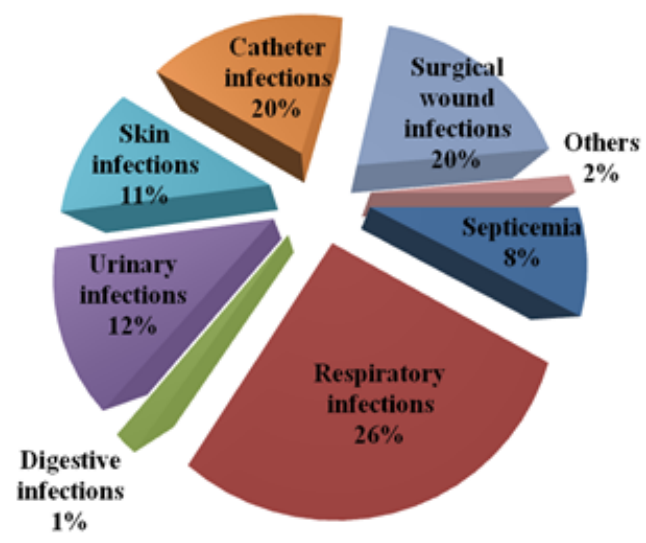

Fig.2. Clinical entities of HAl in 2014-2016 period

digestive infections respectively. On the last place, other infections are represented by otitis and conjunctivitis.

Considering the etiology of HAl reported in 2014-2016 period, showed in table 1, this reveals that the most of healthcare associated infections are caused by Klebsiella pn., Staphylococcus aureus, Pseudomonas sp. and Acinetobacter baumanii.

According to antibiotic resistance data, Gram(-) germs involved in HAl etiology proved to be multidrug resistant as a certainty of pathogenicity.

FTIR spectroscopy shows that when sample molecules absorb energy only vibrational energy transitions undergo in the mid-IR region. Infrared radiation inducing vibrations contains tensions and strains of inter-atomic bonds and modification of bonds angles. The molecules absorb only selected frequencies in the IR domain, therefore will absorb those corresponding to their natural vibrational frequency causing an amplitude increase of chemical bonds vibration. Thus is possible an association between vibration frequency and a particular bond type. Typical infrared spectra for ampicillin, amoxicillin, tetracycline and chloramphenicol are shown in figure 3 .

Amoxicillin belongs to $\beta$-lactam class being effective for bacterial infections treatment. Its action inhibits the cross-linkage between polymer chains of gram $(+)$ cell wall bacteria and gram(-) bacteria.

FTIR spectroscopy was used to highline the intaractions between the molecules at functional groups level. Ampicillin is a semi-synthetic penicillin preserving antibacterial spectrum against gram (+) bacteria and having an enhanced action against gram(-) ones due to its great skill to penetrate the outer membrane of these microbes.

Chloramfenicol and tetracycline are structurally dissimilar and broad-spectrum antibiotics. These drugs commonly act by stopping the protein synthesis in microorganisms being used in several infections caused by $\operatorname{gram}(+)$ and gram(-) bacteria, rickettsiae and chlamydiae.

IR spectra of these antibiotics reveal the presence of all characteristics peaks of them.

Multidrug resistance occurs when bacteria produce enzymes that inactivate the anbtibiotic molecule rendering the antibiotic incapable to destroy for its target. The mechanism of acquired antibioresistance implies the production of bacterial enzymes capable to produce chemical changes to the active molecule.

In case of aminoglycosides the presence of aminoglycoside modifying enzymes covalently modify the amino groups or hydroxyl of the antibiotic molecule. The mechanism of $\beta$-lactam resistance is related to the destruction of the drug molecule by the action of $\beta$ lactamases which destroy the amide bond of the $\beta$-lactam ring making the antibiotic inefficient.

Table 1

ETIOLOGY OF HAI REPORTED IN 2014-2016 PERIOD

\begin{tabular}{|c|c|c|c|c|c|c|c|c|}
\hline \multirow{2}{*}{ Etiological agent } & \multicolumn{2}{|c|}{$\mathbf{2 0 1 4}$} & \multicolumn{2}{|c|}{$\mathbf{2 0 1 5}$} & \multicolumn{2}{c|}{2016} & \multicolumn{2}{c|}{ TOTAL } \\
\cline { 2 - 10 } & Nr. & $\%$ & Nr. & $\%$ & Nr. & $\%$ & Nr. & $\%$ \\
\hline Klebsiella pn. & 29 & 22.0 & 27 & 23.5 & 42 & 19.6 & 98 & 21.3 \\
\hline Pseudomonas sp. & 18 & 13.6 & 20 & 17.4 & 30 & 14.0 & 68 & 14.8 \\
\hline $\begin{array}{c}\text { Staphylococcus } \\
\text { Aureus }\end{array}$ & 24 & 18.2 & 20 & 17.4 & 48 & 22.4 & 92 & 20.0 \\
\hline $\begin{array}{c}\text { Acinetobacter } \\
\text { baumanii }\end{array}$ & 12 & 9.1 & 18 & 15.7 & 13 & 6.1 & 43 & 9.3 \\
\hline Enterococcus sp. & 6 & 4.5 & 8 & 7.0 & 7 & 3.3 & 21 & 4.6 \\
\hline Enterobacter sp. & 14 & 10.6 & 3 & 2.6 & 6 & 2.8 & 23 & 5.0 \\
\hline E. Coli & 12 & 9.1 & 4 & 3.5 & 13 & 6.1 & 29 & 6.3 \\
\hline $\begin{array}{c}\text { Stenotrophomonas } \\
\text { maltophylia }\end{array}$ & 3 & 2.3 & 7 & 6.1 & 9 & 4.2 & 19 & 4.1 \\
\hline Proteus mirabilis & 2 & 1.5 & 1 & 0.9 & 4 & 1.9 & 7 & 1.5 \\
\hline Serratia sp. & 2 & 1.5 & 0 & 0.0 & 4 & 1.9 & 6 & 1.3 \\
\hline Candida sp. & 6 & 4.5 & 3 & 2.6 & 7 & 3.3 & 16 & 3.5 \\
\hline Rotavirus & 2 & 1.5 & 2 & 1.7 & 29 & 13.6 & 33 & 7.2 \\
\hline Measles virus & 2 & 1.5 & 2 & 1.7 & 2 & 0.9 & 6 & 1.3 \\
\hline TOTAL & 132 & & 115 & & 214 & & 461 & \\
\hline
\end{tabular}




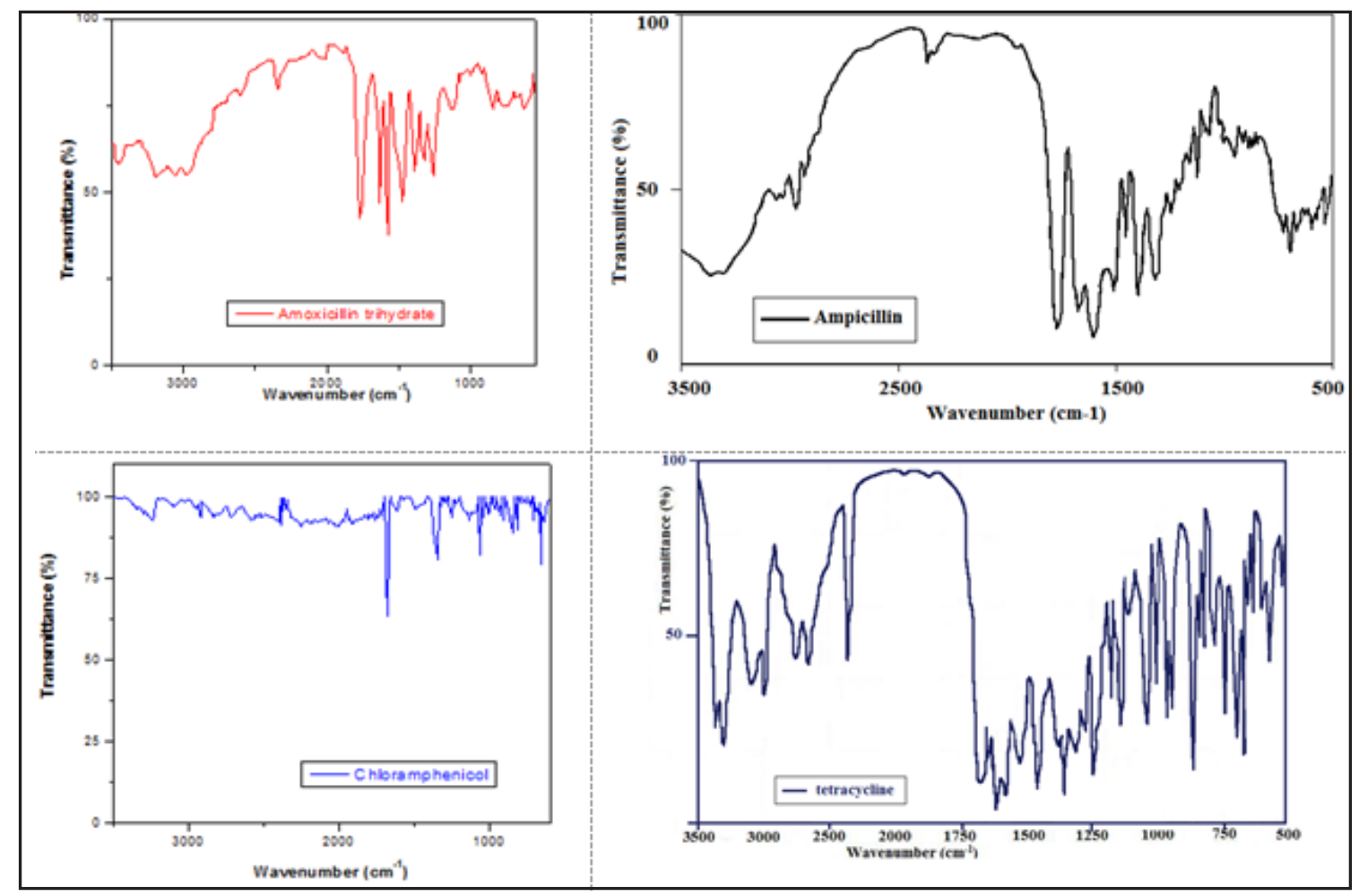

Fig. 3. FTIR spectra for amoxicillin, ampicillin, chloramphenicol and tetracycline

\section{Conclusions}

Mechanism of antibiotic resistance implies the ability of different microorganisms to multiply in the presence of an antimicrobial drug that normally limit or destroy the pathogen agent. Various bacterial pathogens are being reported developing multidrug resistance as a result of cumulative acquirement of resistance features against differentantibiotics. Multidrug resistance is a serious health threat because of infections caused by resistant bacteria knowing that some pathogens struggle to multiple types of antibiotics.

According to these, multidrug resistant infections can be prevented in many ways such as hand washing, safe food preparation, immunization and administrating antibiotics only when necessary. Moreover, avoiding infections also stops prevalence of resistant bacteria.

\section{References}

1.COSGROVE, S.E, Clin Infect Dis, 42(Suppl 2), 2006, p. 82. 2.DIAZGRANADOS, C.A., ZIMMER, S.M., KLEIN, M., JERNIGAN, J.A., Clin Infect Dis., 41, no. 3, 2005, p. 327.

3.SYDNOR, E.R., PERL, T.M., Clin Microbiol Rev., 24, no. 1, 2011, p. 141.

4.CALFEE, D. P., Annual Review of Medicine. 63, 2012, p. 359.

5.DEVRAJANI, B. R., SHAH, S. Z., DEVRAJANI, T., QURESHI, G. A., World J ournal of Medical Sciences., 4 (1), 2009, p. 13.

6.SCHABERG, D. R., CULVER, D. H., GAYNES, R. P., American Journal of Medicine. 91, no. 3B, 1991, p. 72S.

7.CALIN, A.M., DEBITA, M., DRAGOMIR, R., STEFANESCU, O.M., BUDACU, C., SZALONTAY, A.S., Rev Chim (Bucharest), 68, no. 11, 2017, p. 2618

8.DEBITA, M., MUSAT, C., MEREUTA, E., RUS, M., MEREUTA, C., FULGA, I., GANEA, D., Rev Chim (Bucharest), 68, no. 9, 2017, p. 2048. 9.ROMAN, I., CIORTAN, S., BIRSAN, I.G., DEBITA, M., Mat. Plast., 52 , no. 4, 2015, p. 529.
10.TRANDAFIR, L.M., FRASINARIU, O.E., CHIRIAC, M.I., MIRON, I., Medical-Surgical J ournal-Revista Medico-Chirurgicala, 121, no. 2, 2017, p. 313.

11.GLOD, M., DAMIR, D., NICHITUS, S., CALIN, G., DUCEAC, L.D., GORGAN, D.L., TASCU, S., CIUHODARU, M.I., Rev. Chim. (Bucharest), 69, no. 3, 2018, p. 609.

12.TRANDAFIR, L.M., ANTON-PADURARU, D.T., MIRON, I., INDREI, L.L., Revista de Cercetare si Interventie Sociala, 49, 2015, p. 205. 13.CHUMA, T., MIYASAKO, D., DAHSHAN, H., TAKAYAMA, T., NAKAMOTO, Y., SHAHADA, F., AKIBA M., AND OKAMOTO K., Front. Microbiol., 4, 2013, p. 113.

14.WATKINS, R.R., PAPP-WALLACE, K.M., DRAWZ, S.M., BONOMO, R.A., Front. Microbiol., 4, 2013, p. 392.

15.ZENG, X., AND LIN, J., Front. Microbiol., 4, 2013, p. 128.

16.SHI, K., CALDWELL, S.) ., FONG, D.H., BERGHUIS, A.M., Front. Cell. Infect. Microbiol., 3, 2013, p. 22.

17.RAMIREZ, M.S., NIKOLAIDIS, N., TOLMASKY, M.E., Front. Microbiol., 4, 2013, p. 121.

18.WILSON, D.N., Nat Rev Microbiol., 12, no. 1, 2014, p. 35.

19.RAMIREZ, M.S., TOLMASKY, M.E., Drug Resist Updat., 13, no. 6 , 2010, p. 151.

20.HOLLENBECK, B.L., RICE, L.B., Virulence., 3, no. 5, 2012, p. 421. 21.SCHWARZ, S., KEHRENBERG, C., DOUBLET, B., CLOECKAERT, A., FEMS Microbiol Rev., 28, no. 5, 2004, p. 519.

22.ABRAHAM, E.P, CHAIN, E., Nature, 146, 1940, p. 837

23.D'COSTA, V.M., KING, C.E., KALAN, L., MORAR, M., SUNG, W.W., SCHWARZ, C., FROESE, D., ZAZULA, G., CALMELS, F., DEBRUYNE, R., GOLDING, G.B., POINAR, H.N., WRIGHT, G.D., Nature., 477, no. 7365, 2011, p. 457.

24.BUSH, K., Ann N Y Acad Sci., 1277, 2013, p. 84.

25.PATERSON, D.L., BONOMO, R.A., Clin Microbiol Rev., 18, no. 4, 2008, p. 657.

Manuscript received: 26.07 .2018 